\title{
Lung health in a changing world
}

\author{
Matthew J Peters ${ }^{1,2}$, Jane E Bourke ${ }^{3}$
}

\section{Respiratory health is threatened by changes to our climate and environment - but there is also good news}
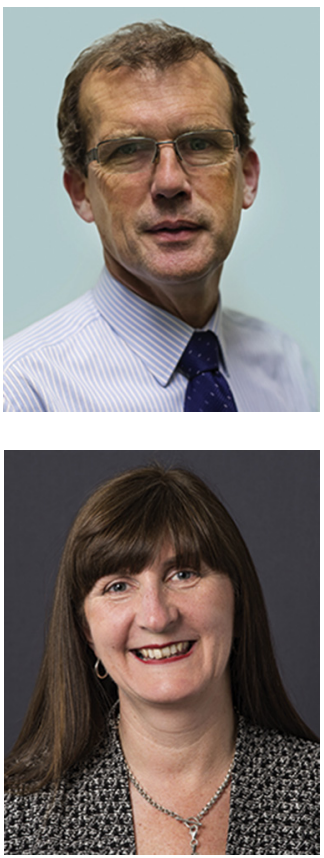

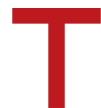
his respiratory medicinethemed issue of the $M J A$ coincides with the meeting in Sydney this month of the Asia Pacific Society of Respirology, which has the title, "Lung health in a changing world". It provides us with an opportunity to reflect on some of the major factors affecting respiratory health in Australia and its near neighbours, including questions discussed in recent issues of this Journal.

\section{Climate change}

Climate change is real and will affect lung health. Heatwaves increase mortality among people with chronic lung disease. ${ }^{1}$ Pseudomonas aeruginosa colonisation in people with cystic fibrosis increases in warmer climates, and lung function declines as temperatures rise. $^{2}$ Extended, more intense wet seasons in tropical regions will also have health consequences, which in endemic areas will include the increasing incidence of pulmonary and systemic melioidosis, an infection caused by the soil and water bacterium Burkholderia pseudomallei; ${ }^{3}$ the pathogen may even migrate south if subtropical soils prove receptive. It is less clear whether major storm events will exacerbate this problem, ${ }^{4}$ but it will be amplified if population policies are adopted that lead to rural areas of northern Australia being developed. ${ }^{5}$ Conditions associated with thunderstorm asthma - dry periods followed by storms may become more frequent just as cities expand into previously rural areas. ${ }^{6}$ The features of patients presenting to an emergency department during the November 2016 thunderstorm asthma event in Melbourne are explored in this issue of the Journal.

\section{Atmospheric pollution}

Australia has relatively good air quality compared with many of our Asian neighbours. However, the levels of particulate pollution, especially of particles of less than $2.5 \mu \mathrm{m}$ diameter $\left(\mathrm{PM}_{2.5}\right)$, are associated with increased risks of pneumonia, asthma, and chronic obstructive pulmonary disease. ${ }^{8}$ In Australia, $\mathrm{PM}_{2.5}$ levels are highest along urban transport corridors that have been selected as priority areas for further increasing urban density. In contrast, pollution in Asia is an evolving tragedy in man-made environments unsafe for human habitation. There are three

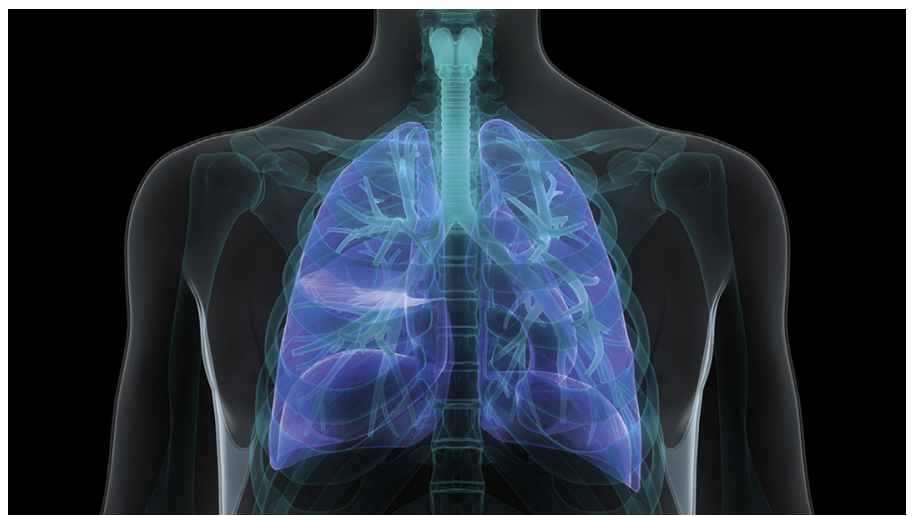

major themes here: indoor air pollution caused by the burning of biomass fuels, episodic pollution peaks related to seasonal factors in northern Asia and unchecked forest fires further south, and persistent high pollution in many cities in China and other large Asian cities; in urbanised India, $\mathrm{PM}_{2.5}$ levels can peak at values 100 times greater than experienced in Sydney. ${ }^{9}$ Air pollution may soon rival smoking as a cause of lung cancer in China.

\section{Occupational safety}

As recently exemplified by reports of pneumoconiosis among coal miners in Queensland, occupational dust exposure remains a serious problem, even in Australia. ${ }^{10}$ Commercial pressures resulting from falling commodity prices may lead to corner-cutting that puts workers at risk. Asbestos in the built environment will become an even greater hazard, both for workers and home renovators, as industrial, commercial and residential properties reach the end of their serviceable lives, ${ }^{11}$ and perhaps also as the fear of asbestos exposure begins to fade in the assumption that it is a problem of the past. Two helpful reviews in this issue of the $M J A$ discuss further the current status of occupational lung disease and mesothelioma in Australia. ${ }^{12,13}$

\section{Antimicrobial resistance}

The 20th century witnessed major advances in the treatment of many infectious diseases; some of this progress, however, is now unravelling. The emergence of drug-resistant strains of Mycobacterium tuberculosis underscores the importance of screening migrants and refugees and clinical intervention before they settle in Australia. Drug-resistant tuberculosis ranging from cases that can be managed, if only with difficulty, to essentially untreatable patients - will progressively spread from patients who have been inadequately treated to people directly infected by resistant strains during childhood. ${ }^{14}$ The proportion of hospitalised patients with pneumococcal lung infections who recover only with the aid of antibiotic 
therapy - perhaps as high as $25 \%^{15}$ - may decline, as no new antibiotic class has emerged since the quinolones were introduced in the early 1960s. Essentially untreatable gram-negative infections are already problematic, particularly after surgery and in the intensive care unit. ${ }^{16}$

\section{Novel infectious diseases}

In recent decades, each American presidency has been accompanied by a serious emerging infectious viral disease: the human immunodeficiency virus, the West Nile virus, the severe acute respiratory syndrome (SARS) and Middle East respiratory syndrome (MERS) coronaviruses, the Zika virus, and the H1N1/09 influenza virus, to name the most important. While the rate at which new diseases emerge may not have increased, their pathogens spread at the speed of available transport, relying on the interconnectedness of communities; ${ }^{17}$ only the timing and nature of epidemics are uncertain. Increasing family, trade and tourism links with India and China ${ }^{18}$ undoubtedly bring many positives for Australia, but also increase our exposure to new pathogens. The presumption that we could adequately build our defences after watching an epidemic unfold in the Northern Hemisphere is flawed.

\section{Not all doom and gloom}

But we should grant similar attention to positives and opportunities in lung health. Profound improvements are possible if the current generation of Australian teenagers, 98\% of whom do not smoke, ${ }^{19}$ remain smoke-free. But the current push to popularise e-cigarettes, which accelerate progression to smoking 3- to 4 -fold, ${ }^{20}$ threatens this opportunity. The epidemiology of smoking has changed in Australia, and will change in Asia, but new strategies for targeting residual pockets of smokers are being developed..$^{21}$ Further, it may be time for Australia to consider regulating how and where tobacco is sold, as discussed in this issue of the MJA. ${ }^{22}$ Whether it would be feasible to take legal action against the tobacco industry to recover health care costs is another interesting question. ${ }^{23}$ Determined political action is required to limit global warming, to control air pollution, and to counteract drivers of deliberately lit forest fires in Asia. There must be a general switch to low emission vehicles, improved public transport infrastructure, and the construction of urban environments that encourage walking, both to improve health generally and to reduce population levels of obesity, a condition that aggravates the effects of intrinsic lung disease. ${ }^{24}$

New knowledge provided by the basic sciences and technological advances continue to deliver benefits for patients. Advanced understanding of protein structure and accelerated drug screening are facilitating novel therapies; ivacaftor, for example, is already improving the lives of selected patients with cystic fibrosis. ${ }^{25}$ More effective vaccination against known and future infectious diseases is essential, and efforts to re-assert control of tuberculosis despite spreading drug resistance may depend on such advances.

Circulating tumour DNA testing for some lung cancers is now available, offering the promise of earlier and more accurate diagnosis, ${ }^{26}$ while molecular profiling can match patients with more effective treatments. New genetic knowledge, including that derived from whole genome sequencing, will be harnessed in ways that are currently unimaginable, but potential applications will also provide novel ethical challenges. ${ }^{2}$
Our country and our region are changing, and the changes are dramatically influencing our lung health. The coming decades offer both risk and opportunity: buckle up for an interesting ride!

Competing interests: No relevant disclosures.

Provenance: Commissioned; externally peer reviewed.

( 2017 AMPCo Pty Ltd. Produced with Elsevier B.V. All rights reserved.

1 Witt C, Schubert AJ, Jehn M, et al. The effects of climate change on patients with chronic lung disease: a systematic literature review. Dtsch Arztebl Int 2015; 112: 878-883.

2 Collaco JM, McGready J, Green DM, et al. Effect of temperature on cystic fibrosis lung disease and infections: a replicated cohort study. PLoS One 2011; 6: e27784.

3 Parameswaran U, Baird RW, Ward LM, Currie BJ. Melioidosis at Royal Darwin Hospital in the big 2009-2010 wet season: comparison with the preceding 20 years. Med J Aust 2012; 196: 345-348. https://www.mja.com.au/journal/2012/196/5/melioidosis-royaldarwin-hospital-big-2009-2010-wet-season-comparison-preceding

4 Stewart JD, Smith S, Hanson J. Melioidosis in Far North Queensland is not correlated with severe weather events. Med J Aust 2017; 207: 394.

5 Australian Government, Office of Northern Australia. Our north, our future: white paper on developing northern Australia. Canberra: Commonwealth of Australia, 2015. http://northernaustralia.gov.au/files/files/NAWP-FullReport.pdf (accessed Sept 2017)

6 Lindstrom SJ, Silver JD, Sutherland MF, et al. Thunderstorm asthma outbreak of November 2016: a natural disaster requiring planning. Med J Aust 2017; 207: 235-237. https://www.mja.com.au/journal/2017/207/6/thunderstorm-asthma-outbreaknovember-2016-natural-disaster-requiring-planning

7 Sutherland MF, Le Portelli E, Collins AL, et al. Patients with thunderstorm asthma or severe asthma in Melbourne: a comparison. Med J Aust 2017; 207: 434-435.

8 Ren C, Tong S. Health effects of ambient air pollution - recent research development and contemporary methodological challenges. Environ Health 2008; 7: 56.

9 World Health Organization. Ambient air pollution: a global assessment of exposure and burden of disease. Geneva: WHO, 2016. http://www.who.int/phe/publications/airpollution-global-assessment/en/ (accessed Aug 2016).

10 Zosky GR, Hoy RF, Silverstone EJ, et al. Coal workers' pneumoconiosis: an Australian perspective. Med J Aust 2016; 204: 414-418. https://www.mja.com.au/journal/2016/ 204/11/coal-workers-pneumoconiosis-australian-perspective

11 Olsen NJ, Franklin PJ, Reid A, et al. Increasing incidence of malignant mesothelioma after exposure to asbestos during home maintenance and renovation. Med J Aust 2011; 195: 271-274. https://www.mja.com.au/journal/2011/195/5/increasing-incidence-malignantmesothelioma-after-exposure-asbestos-during-home

12 Hoy RF, Brims F. Occupational lung diseases in Australia. Med J Aust 2017; 207: 443-448.

13 Musk AW, de Klerk N, Brims FJ. Mesothelioma in Australia: a review. Med J Aust 2017; 207: 449-452.

14 Millard J, Moore DAJ. Multidrug resistant tuberculosis. BMJ 2015; 350: h882.

15 Dowling HF, Lepper MH. Effect of antibiotics (penicillin, aureomycin, and terramycin) on fatality rate and incidence of complications in pneumococcic pneumonia: comparison with other methods of therapy. Am J Med Sci 1951; 222: 396-402.

16 Sidjabat HE, Paterson DL. Multidrug-resistant Escherichia coli in Asia: epidemiology and management. Expert Rev Anti Infect Ther 2015; 13: 575-591.

17 Charu V, Zeger S, Gog J, et al. Human mobility and the spatial transmission of influenza in the United States. PLoS Comput Biol 2017; 13: e1005382.

18 Australian Government, Department of Foreign Affairs and Trade. Composition of Australia's trade in services with our major trading partners: 2006 to 2016. http://dfat.gov.au/about-us/publications/Documents/australias-trade-in-services2006-2016.pdf (accessed Aug 2017).

19 Australian Institute of Health and Welfare. National Drug Strategy Household Survey (NDSHS) 2016 - key findings. https://www.aihw.gov.au/reports/ illicit-use-of-drugs/ndshs-2016-key-findings/contents/tobacco-smoking (accessed Aug 2017)

20 Soneji S, Barrington-Trimis JL, Wills TA, et al. Association between initial use of e-cigarettes and subsequent cigarette smoking among adolescents and young adults: a systematic review and meta-analysis. JAMA Pediatr 2017; 171: 788-797.

21 Bonevski B, Borland R, Paul CL, et al. No smoker left behind: it's time to tackle tobacco in Australian priority populations. Med J Aust 2017; 207: 141-142. https://www.mja.com.au/ journal/2017/207/4/no-smoker-left-behind-its-time-tackle-tobacco-australian-prioritypopulations 
22 Freeman B. Challenging how tobacco is sold in Australia. Med J Aust 2017; 207: 417-418.

23 MacKenzie R, LeGresley E, Daube M. Legal does not mean unaccountable: suing tobacco companies to recover health care costs. Med J Aust 2017; 207: 419-421.

24 O'Donnell DE, Ciavaglia CE, Neder JA. When obesity and chronic obstructive pulmonary disease collide: physiological and clinical consequences. Ann Am Thorac Soc 2014; 11: 635-644.
25 Accurso FJ, Rowe SM, Clancy JP, et al. Effect of VX-770 in persons with cystic fibrosis and the G551D-CFTR mutation. N Engl J Med 2010; 363: 1991-2003.

26 Zhang C, Wei B, Li P, et al. Prognostic value of plasma EGFR ctDNA in NSCLC patients treated with EGFR-TKIs. PLoS One 2017; 12: e0173524.

27 Berg JS, Khoury MJ, Evans JP. Deploying whole genome sequencing in clinical practice and public health: meeting the challenge one bin at a time. Genet Med 2011; 13: 499-504. 